\title{
Community Radio in Ireland: "Defeudalising" the Public Sphere?
}

\begin{abstract}
The growth in interest and research in community radio worldwide over the last few decades is a welcome development. While, as noted by Jankowski (2003), a first generation of research has been largely empirical in nature, describing and analysing the organisation and operation of stations in different contexts, more recently a second generation of work has begun to emerge which aims at grounding empirical studies within broader theoretical frameworks, most notably those relating to democracy and the public sphere. The specific components of the public sphere remain somewhat underdeveloped in these studies however. This article aims to contribute to this literature through an examination of community radio in Ireland within a framework drawn from evolving work the work of Habermas and associated deliberative, social and media theorists. The article, drawing on a detailed study of four community stations in Ireland, identifies elements of community radio which contribute towards a "defeudalisation" of the public sphere as well as highlighting challenges in this regard. Although situated within a specific context, with Irish community radio operating within a comparable regulatory environment to both that in Australia and the United Kingdom, the article draws lessons of specific interest to researchers and activists in these domains, as well as offering a framework of use to community radio researchers interested in examining the sector's contribution to the re-animation of the public sphere more globally.
\end{abstract}

\section{Introduction}

The growth in interest and research in community radio over the past number of decades is a welcome development given both its uniqueness within the broader 'mediapolis' (Silverstone 2007, 31) and the enthusiasm, energy and commitment of its promoters. A first generation of research in the area, focusing on the organisation and operation of stations within their broader regulatory environment, has highlighted the distinctiveness of the sector compared to commercial and public broadcasting services. Evidence of the role of community stations in building communities by enabling dialogue between different sections of the community (Siemering 2000; Forde et al 2002; Martin and Wilmore 2010), in reflecting and constructing local culture (Meadows et al 2005), in fostering and consolidating a sense of place (Keough 2010), in reducing the isolation of certain communities (Read and Hanson 2006) and in reengaging marginalised groups and promoting progressive social change (Barlow 1988, Sussman and Estes 2005, Baker 2007) highlights the distinctiveness of the sector vis-à-vis public service or commercial broadcasters. As Jankowski and Prehn (2003) outline, the defining characteristics of community media set them apart from their counterparts at both commercial and public service levels in both their aims - providing news and information relevant to the needs of community members, engaging members in public discussion and contributing to their social and political empowerment - and in their structures of ownership, 
control and financing which are often shared by local residents. In short, community radio breaks with traditional, mainstream models of media production in that community members are not an audience in the traditional sense. Rather, they are potential and actual broadcasters and producers, active participants in their local communication project.

The distinctiveness of this model of broadcasting clearly has implications for theories of the public sphere, a sphere which Habermas (1962/1989) has argued has been 'refeudalised' by the increasing control by state and commercial elites over mainstream media. These theoretical implications have formed the basis of a second generation of research. In a study of community radio in India, Saeed (2009) focuses on the legislative challenges to local activists' attempts to re-animate the public sphere, while in a study of the sector in Australia, Meadows et al argue that, in providing communities with 'alterNative' ideas and assumptions $(2005,183)$, community radio has extended the idea of the mainstream public sphere. In one of the most theoretically comprehensive contributions to date, Stiegler (2009) both demonstrates the failure of mainstream broadcasting as a public sphere within the US and draws in particular on Benjamin Barber's model of 'strong democracy' (Barber 1984, after Stiegler $(2009,50-51))$ to elucidate what small-scale public spheres might look like within the context of community radio.

While illuminating different characteristics of the normative public sphere in the context of the cases under investigation, the specific components of the public sphere, as theorised by Habermas and his followers, remain somewhat underdeveloped in these studies however. This article aims to bridge this gap through an examination of community radio in Ireland within a framework drawn from the evolving work work of Habermas and associated deliberative, social and media theorists. The article draws on a detailed study of four community stations in Ireland. This research, conducted by the authors over the seven month period October 2009 to April 2010, combined both an ethnographic approach, where time was spent in each of the four stations observing how the stations operated and informally chatting with volunteers and staff, with 33 individual interviews with staff, volunteers and community members in each of the four communities. Examining the empirical findings from this research (see Gaynor and O'Brien, 2010 for the complete research report) through the inter-related theoretical lenses of the public sphere, deliberation and civil society which lie at the heart of the community radio project, the article highlights elements of community radio which contribute towards a 'defeudalisation' of the public sphere as well as highlighting challenges in this regard. Although situated within a specific context, with Irish community radio operating within a comparable regulatory environment to both that in Australia and the United Kingdom, the article draws lessons of specific interest to researchers and activists in these domains, as well as offering a framework of use to community radio researchers interested in examining the sector's contribution to the re-animation of the public sphere more globally. 


\section{Toward a defeudalised public sphere: A framework of analysis}

Jürgen Habermas' sharp critique of capitalism as set out in his 1962 publication, The Structural Transformation of the Public Sphere, has been pivotal to the idea that the normalised ideal of publicity constitutes the key social function of the media. Contrasting the various fora of an active, participative bourgeois public sphere - typified by the coffee houses of eighteenth century Germany - with the increasingly commercialised and privatised public spheres of contemporary society controlled by mainstream media and elites, Habermas argued that the commercialisation of the media in the 1800s and 1900s turned 'rationalcritical' debate into 'cultural consumption' with the public sphere taking on 'feudal features' $(1962 / 1989,195)$ as powerful institutions of both market and state took it over. Comparing the public sphere of capitalist society with that of earlier feudal societies where ruling elites sought to dominate their subjects through control of the public sphere, Habermas argued that active citizens have been transformed into passive consumers - of goods, services, politics and spectacle. The result, Habermas (1989) argued, is a 'decayed form of the bourgeois sphere' (215), a 'manipulated public sphere' (217) and a 'manufactured public sphere' (217).

Although Habermas' bleak critique of modernity in The Structural Transformation offered no emancipatory alternative, his 'linguistic turn' (Holub 1991, 10) in the 1980s through his theory of communicative action proffered a normative model of rational-critical debate through which political emancipation may be achieved. Arguing that the 'self-organised public sphere must develop a prudent combination of power and self-restraint that is needed to sensitise the self-steering mechanisms of the state and the economy' (1987, 365), Habermas's work in the 1980s depicts the public sphere as a site of rational critical deliberation open and accessible to all with citizens employing deliberative norms which are inclusive, reasoned and reflective, and aimed at reaching common understanding and consensus (Habermas 1987) Within this space, each participant has an equal opportunity to be heard, to introduce topics, to make contributions and to arrive at decisions motivated solely by the strength of argument $(1996,305)$. Thus a first normative requirement for a reinvigorated, re-animated and 'de-feudalised' public sphere is that it be open and inclusive to all. This clearly has implications for the role and agency of media institutions within this public sphere. At the heart of debates on the social functions of the media is the Enlightenment notion of publicity - citizens' freedoms to express and publish opinion, the 'right to communicate' (Splichal, 2006, 11-17). As we have seen, this ideal is reflected in the ethos of community radio where 'the right to communicate' is highlighted by policy makers (see AMARC 1994) and practitioners alike. While there appears to be broad agreement on this fundamental norm among community radio scholars and analysts, Kitty van Vurren (2006) in a study of community radio in Australia, highlights a critical paradox between the ideals of offering a legitimate alternative voice to the mainstream public sphere - the main function of community radio in her view - and affording full access and participation to all. Her argument that sustaining the value of the public sphere rules out the normative ideal of a 
universally open and accessible public arena raises important questions in relation to who gets to participate within community public spheres, and to what end. Should community radio provide a space for a broad-range of discourses or should these be limited to more marginalised voices with a view to advocating and effecting social change as proposed by a number of community radio commentators (Barlow 1988, Sussman and Estes 2005, Baker 2007)?

This question is possibly best considered by returning to Habermas' theory of communicative action. The communicative norms he has proposed have drawn considerable debate and critique, serving as a catalyst for a wide body of work within the fields of political and social theory on public deliberation, its role within democracy (in a post-liberal sense), and the role of civic associations and institutions in this regard. Heavily influenced by Enlightenment thinkers, Habermas' earlier work emphasised the importance of logical argument as a means by which views, opinions and analyses are elucidated with the aim of participants arriving at common understandings and views of particular issues under discussion, reaching consensus and agreement on these (1987). These norms have both inspired and drawn considerable criticism from a wide range of theorists. The vast literature on deliberative democracy draws significantly on Habermas' work. Deliberative democrats advocate a public of overlapping discourses aimed at making sense of the world (Dryzek, 2000), a shared conversation 'of mutually interlocking and overlapping networks and associations of deliberation, contestation and argumentation' (Benhabib 1996, 74). For deliberative democrats therefore, the public sphere is a space open and accessible to all with unrestricted communication taking place across a series of conversations. Habermas' communicative norms have also met with some sharp critique however, most particularly from post-structuralists for whom Habermas delivers an overly rationalist conception of the public sphere which, despite claims that it makes room for difference, fails to adequately theorise pluralism and power. Specifically, critics argue that the norms of rational discourse with their deliberative emphasis on communicative reason and consensus ignore the pluralist and inevitably conflictual nature of society (Mouffe 1996, 2005) and exclude individuals and groups for whom more emotive, less bounded and less rational forms of communication are the norm (Young 2000, 2003) thus reinforcing and reproducing existing exclusions and inequalities as powerful actors come to dominate the public sphere (Fraser 1992). Thus, for these critics, Habermas' norms of rational, bounded discourse together with his aim of mutual understanding and consensus undermine his norms of inclusivity, access and participation, most particularly for those marginalised by the mainstream public sphere.

The question for analysts and activists thus becomes 'who is the community encompassed within the community public sphere?' Is there a need for a multiplicity of public spheres including those aimed specifically at more marginalised groups as proposed by Fraser (1992) and should community radio aim at opening spaces specifically for these marginalised groups or can a community public sphere accommodate a range of voices and communication acts? 
While Habermas and his followers are often juxtaposed in binary opposition to these socalled 'difference democrats' who argue for a diversification of communication norms, both Habermas himself and certainly many contemporary deliberative democrats have moved a long way over time in taking on board these criticisms and diversifying their conception of the public sphere. Habermas has moved from a narrowly universal to a much more plural conception of public spheres (Brady 2004, Dahlberg 2005) and while consensus lay at the heart of early deliberative models, later contributions have considerably modified its role and importance, moving beyond a purely reason-centred, consensus oriented emphasis (Dryzek 2000). Deliberations are now seen to include a wide range of communication acts accommodating marginalised, disenfranchised groups, including story-telling, song, protests and boycotts (Young 2000, 2003). Indeed Karppinen, Moe and Svensson (2008), making a case for 'theoretical eclecticism', argue that, though differences still exist between different theorists, these are not so great as they once were. The authors argue that both (or all) poles have value as critical perspectives which complement each other $(2008,18)$. Thus, for many theorists, the ideals of an espousal of alternatives and universal access appear largely compatible with deliberations within a public sphere which is now seen to embody a wide range of communication acts, acts which promote critique, understanding, contestation and accommodation alike.

While normatively therefore, there appears to be some agreement on the need for an open and inclusive public sphere (or spheres, depending on how we define 'community' in the context of specific community stations), together with the communication norms these entail, allowing for diverse communication acts which include contestation and resistance, key challenges remain at a practical level in promoting participation within these spheres. In the specific context of community radio, Stiegler identifies civic apathy as a barrier to full participation $(2009,53-54)$ while, in the context of media and the public sphere more broadly, Dahlgren $(2002,19-22)$ highlights the importance of a vibrant civic culture in promoting civic participation. For Habermas, civic associations have a key role to play in both animating debate and promoting participation within public spheres, and in forcing the official circuits of power to be attentive and responsive to new issues arising within these spheres $(1996,370)$. This civic associational function has been echoed by a number of deliberative theorists (Benhabib 1996; Dryzek 1990, 2000) together with social theorists more broadly. In one of the most comprehensive and influential contributions within postCold War debates on the links between civil society and democracy, Cohen and Arato draw on Habermas' theory of communicative action and argue that (1992, ix-x), 'The political role of civil society in turn is not directly related to the control or conquest of power but to the generation of influence through the life of democratic associations and unconstrained discussion in the cultural public sphere. 'Civil society, in other words, plays a key role in promoting the civic culture which opens up the public sphere for more inclusive, broader deliberation and debate on issues of public interest and concern. In the context of community radio therefore, not only the stations themselves but also civic associations more broadly have a key role to play in promoting participation within community spheres. 
This normalised function attributed to civil society perhaps underestimates the potential for hegemonic dominance and adversarial interest group politics, the type of deliberation which deliberative democrats reject. It furthermore appears to ignore the power imbalances or inequalities inherent in any and all communities. Habermas, deliberative and a number of civil society theorists remain vague on how exactly specific actors - community radio activists and civic associations more broadly - prevent communication distortions or unequal access to and participation in the public sphere in order to 'sell' particular messages to the public. Given the core norms of inclusivity, access and participation, this raises a question around the possible need for some form of external intervention to assure the diverse, unconstrained communication within the public sphere advocated by deliberative democrats. This brings us to the issue of regulation.

In his re-thinking of the Marxist concepts of base and superstructure within a communications framework, Habermas' distinction between the 'system' and the 'life-world' argues strongly against both market and state intervention in the public sphere. Arguing that problems arise when the system - the powerful domains of market, state and organised interests within social life - invades or 'colonises' the practical domain of the everyday lifeworld - the civic domain / public sphere where shared common understandings develop within and across various social groups, Habermas argues for a defence of the life-world from the institutions of both state and market (Habermas 1987). Moreover, arguing that both the state and capitalism need to be 'socially tamed', Habermas $(1987,363)$ envisages the shared understandings, views and perceptions formed within the life-world, at the periphery of political life, feeding upward into policy and decision-making within the system at the centre. In Habermas' view, the 'colonisation' of the life-world by the system, most notably the colonisation of the media as a key institution within the life-world by the state and market, has resulted in the crisis of modernity, of which the erosion or refeudalisation of the public sphere is a significant part. In effect, Habermas is arguing for an animation and 'defeudalisation' of the public sphere and a move toward a more responsive, accountable and participatory model of democracy. Habermas' exhortation for a separation of state from the life-world presents fundamental challenges to media institutions - including many community radio stations in this respect. Regulated by the 'system', how can they be active in the 'decolonisation' of the life-world? Splichal's discussion on the contradiction between freedom of the press itself and the publicity function of the media is useful in helping us think through this. Noting that the idea of media autonomy is challenged by the idea of responsibility - the social need to prevent or hinder abuses of power $(2006,7)$, Splichal argues in favour of media regulation, with such regulation aiming at equal availability of influence while guaranteeing individuals' distinctiveness and uniqueness $(2006,18)$. For Splichal, 'The empowerment of individuals with 'communicative power' would pave the way for an effective social communication and public use of reason'. Writing from the broader perspective of civic engagement in the public sphere as a key element of democracy, Cohen and Rogers $(1995,48-9)$ also envisage a role for the state in ensuring that civic associations 
work for the broader good rather than those of particular hegemonic or factional interests. Indeed, Habermas himself acknowledges that 'on account of its anarchic structure, the general public sphere is... more vulnerable to the repressive and exclusionary effects of unequally distributed social power, structural violence, and distorted communication...' (1996, 307-8). Acknowledging the need for some mechanism to prevent this, and accepting that all civil associations are not necessarily what Cohen and Rogers term 'other regarding' $(1995,98)$, an open question remains in relation to the desirability of state regulation in this context and, if so, in what form and with what consequences.

It is apparent from the above discussion that if we are interested in opening up the public sphere, a range of complex issues present themselves. We need to think about who inhabits this space and who does not, how they do so and how they do not, and above all, how the space might be rendered more open and inclusive in the form envisioned by Habermas and his followers. In short, when thinking about the public sphere, we need to examine the structural issues of access, participation and communication, together with the agency of civic and state actors in this regard, addressing as we do so, some of the key questions emanating from the literature to date. This is what we endeavour to do below in our examination of the contribution of community radio to the Irish public sphere.

\section{Community Radio in Ireland: Opportunities and challenges to the defeudalisation of the public sphere}

Community radio in Ireland emerged from a pilot-project established in 1994 by the national broadcasting regulator which licensed eleven stations initially. The AMARC Community Radio Charter for Europe (AMARC, 1994) was adopted by the regulator as a statement of the objectives community stations should aim to achieve. Community radio was defined as follows:

A community radio station is characterised by its ownership and programming and the community it is authorised to serve. It is owned and controlled by a not-for-profit organisation whose structure provides for membership, management, operation and programming primarily by members of the community at large. Its programming should be based on community access and should reflect the special interests and needs of the listenership it is licensed to serve.

(BCI n.d., 3).

Following the pilot project, the regulator supported an expansion of the sector and there are currently (2011) twenty two licensed community stations operating across the country. With the state retaining a central role in the regulation of community radio in Ireland, community radio stations in Ireland exhibit many of the characteristics of normative models more 
broadly. They are run on a non-commercial basis; their programming content reflects local issues; although sometimes employing a small staff, they are largely reliant on community volunteers for both programming and associated administrative tasks; and stations are owned and managed by representatives from within local communities. While, on paper therefore Irish community stations appear to embody many of the characteristics necessary for the animation of local public spheres, a closer examination through the theoretical lens elaborated above permits a more comprehensive picture of the degree to which they succeed in this endeavour.

A brief overview of the four stations included in the study is provided in Table 1 below. As the data illustrate, all four stations are relatively 'new' stations broadcasting within relatively localised areas and with a significant number of volunteers. Notably also, all are funded by a mix of state and community support. This calls into question the feasibility of the autonomy of the life-world from the system as advocated by Habermas and corresponds more closely to the model advocated by Cohen and Rogers. We return to this important issue later. For now, we turn to a more detailed examination of the other elements within the public sphere framework set out in the previous section.

Table 1: A brief overview of the four participating stations

\begin{tabular}{|c|c|c|c|c|}
\hline $\begin{array}{c}\text { Station / } \\
\text { Characteristics }\end{array}$ & Life FM & Liffey Sound & Ros FM & Tipperary MW \\
\hline Established & $\begin{array}{l}\text { License awarded } \\
\text { in 2006, on air } \\
\text { since } 2008 .\end{array}$ & $\begin{array}{l}\text { License awarded } \\
\text { in } 2005 \text {, on air } \\
\text { since } 2006 .\end{array}$ & $\begin{array}{l}\text { License awarded in } \\
2003 \text {, on air since } \\
2005 .\end{array}$ & $\begin{array}{l}\text { Began as pirate station } \\
\text { in1980, awarded a } \\
\text { commercial license in } \\
1990 \text { and a community } \\
\text { license in } 2004 .\end{array}$ \\
\hline Broadcast area & $\begin{array}{l}10 \text { mile radius } \\
\text { around Cork city. }\end{array}$ & $\begin{array}{l}10 \text { mile radius } \\
\text { around West } \\
\text { Dublin. }\end{array}$ & $\begin{array}{l}5 \text { mile radius } \\
\text { around } \\
\text { Roscommon town. }\end{array}$ & $\begin{array}{l}20 \text { mile radius in } \\
\text { Tipperary. }\end{array}$ \\
\hline No. staff (paid) & 4 & $\begin{array}{l}0 \\
\text { (all staff are } \\
\text { voluntary) }\end{array}$ & $\begin{array}{l}3 \\
\text { (1 full-time and } 4 \\
\text { part-time) }\end{array}$ & $\begin{array}{l}12 \\
\text { ( } 4 \text { full-time and } 8 \text { part- } \\
\text { time with hours ranging } \\
\text { from }<3 \text { hours per week } \\
\text { to } 20 \text { hours per week) }\end{array}$ \\
\hline No. volunteers & $\begin{array}{l}60-80 \text { with } 30-40 \\
\text { broadcasting } \\
\text { weekly. }\end{array}$ & $\begin{array}{l}\text { Approx. } 150 \text { with } \\
72 \text { broadcasting } \\
\text { weekly. }\end{array}$ & $\begin{array}{l}\text { Over } 100 \text { with } 17- \\
18 \text { broadcasting } \\
\text { weekly. }\end{array}$ & $\begin{array}{l}\text { Over } 100 \text { with } 51 \\
\text { broadcasting weekly. }\end{array}$ \\
\hline On air & $\begin{array}{l}\text { Mon-Sunday } \\
\text { 7am-midnight, } \\
\text { with repeats }\end{array}$ & $\begin{array}{l}\text { Mon-Friday, } \\
\text { 5pm-midnight; } \\
\text { Sat/Sun, 8am- }\end{array}$ & $\begin{array}{l}\text { Mon-Friday, 2pm- } \\
9 \mathrm{pm} .\end{array}$ & $\begin{array}{l}\text { Mon-Sunday, } 8 \text { am- } 12 \\
\text { midnight, with repeats } \\
\text { through the night. }\end{array}$ \\
\hline
\end{tabular}




\begin{tabular}{|c|c|c|c|c|}
\hline & through the night. & midnight. & & \\
\hline $\begin{array}{l}\text { Estimated } \\
\text { Listenership } \\
\text { Estimates are } \\
\text { from surveys } \\
\text { conducted by } \\
\text { each station. }\end{array}$ & 13,000 per week & 11,000 per week & 13,000 per week & $\begin{array}{l}90 \text { per cent of the } \\
\text { population (sample size } \\
100 \text { ) surveyed in } 2009 .\end{array}$ \\
\hline $\begin{array}{c}\text { Station } \\
\text { /Characteristics }\end{array}$ & Life FM & Liffey Sound & Ros FM & Tipperary MW \\
\hline $\begin{array}{l}\text { Cost per year to } \\
\text { run } \\
\text { (2009 figures) }\end{array}$ & $\begin{array}{l}\text { Total } € 84,000 \\
52 \% \text { from } \\
\text { membership / } \\
\text { donations; } 43 \% \\
\text { from the national } \\
\text { regulator's } \\
\text { programme } \\
\text { funding scheme; } \\
5 \% \text { from } \\
\text { advertising*. }\end{array}$ & $\begin{array}{l}\text { Total } € 35,000 \\
\\
\text { Breakdown not } \\
\text { available but } \\
\text { majority from } \\
\text { fundraising and } \\
\text { the remainder } \\
\text { from the national } \\
\text { regulator's } \\
\text { programme } \\
\text { funding scheme. }\end{array}$ & $\begin{array}{l}\text { Total } € 150,000 \\
83 \% \text { from a } \\
\text { national state } \\
\text { agency's } \\
\text { community } \\
\text { funding } \\
\text { programme; } 17 \% \\
\text { from fundraising. }\end{array}$ & $\begin{array}{l}\text { Total } € 250,000 \\
50 \% \text { from advertising; } \\
32 \% \text { from donations and } \\
\text { fundraising; } 6 \% \text { from } \\
\text { state grant schemes and } \\
2 \% \text { from station } \\
\text { investments. } \\
\text { All funding for staff } \\
\text { salaries comes from a } \\
\text { national state agency's } \\
\text { community funding } \\
\text { programme. }\end{array}$ \\
\hline
\end{tabular}

\section{Inclusion and participation}

As we have already seen, the issues of inclusion and participation are central to public sphere theory. For community radio scholars, the core question arising is the compatibility of universal inclusion and participation with the goal of engaging more marginalised voices and discourses. For community radio activists, this raises the inter-related questions of 'who is the community?' and 'what is the role of the station vis-à-vis this community?'. Under the Irish licensing scheme three of the stations examined falls under the 'geographic community' category while one of the stations is a 'community of interest' station. Notwithstanding this distinction, volunteers and staff in all four stations stressed their openness to all within the geographically delineated communities in which they broadcast. When pressed on this question however, staff and volunteers in all four stations noted they had an emphasis on particular groups within their community. Thus Life FM, the 'community of interest' station carries a distinct Christian message of hope, Tipperary MW caters in particular to the elderly, Ros FM, a station established and managed by representatives from local state-funded social agencies, has a disability ethos built into its mission, and Life FM tends to cater to a younger age group. 
Questioned as to their stations' roles vis-à-vis these communities, the concept of the stations as services to these communities emerged strongly among all actors involved. Across all four stations, staff and volunteers stressed their stations' role in this regard as being two-fold. First, stations were seen as providing an invaluable service in the provision of local information - on news, events, services available. As a staff member of Tipperary MW notes "... with the commercial [stations], it's mainly advertiser focused... with community radio you're focused on the audience at hand. Some of the bulletins would include local issues that wouldn't get on to a bulletin on local commercial stations - minor issues, council notices. It's more of an information point, a locally based information point." And second, stations' roles in reaching out to more isolated and vulnerable members of the community was noted, people for whom the mainstream public sphere has lost relevance and meaning. These findings accord with analyses that see community radio as playing an important role in building and consolidating a sense of community. However, they do not suggest that community stations play a large role in driving or affecting change as argued by other commentators.

An interesting distinction was made by staff and volunteers across all stations between the wider community 'serviced' by the stations and the community of staff and volunteers working within the stations themselves. Across all four stations, this 'community within', as some termed it, exhibits a considerable degree of diversity in terms of gender, age, and cultural background, and all stations appear to have made specific efforts to include more marginalised sections of the population - in particular the unemployed (a rapidly growing category in recessionary Ireland). The benefits of involvement for these groups - as noted by these groups and station managers - once again appears to reflect the service function of the stations, where they are viewed more as a local social enterprise, than as an alternative public sphere as advocated by a number of community media analysts. This is reflected in the three principal benefits identified by volunteers and managers alike. First, for all, the most important benefit is the technical training provided by stations which provides volunteers with the skills to break into other broadcasting spheres. Indeed, community radio is viewed by the many of the volunteers interviewed as an entry point into commercial and public broadcasting stations, where it is hard to get work experience. As volunteers from two stations explain... "As part of my course in Sound Engineering and Media Technology I'm required to do work experience. I tried a lot of stations and it was hard to get someone to take me on... I rang Brian [Life FM station manager] and he met me for interview and took me on..." (Life FM volunteer). "I tried to get interview experience and heard them [Liffey Sound] broadcast in the local shop. I met the station manager. He brought me on to a sports programme and 3 weeks later I got a show..." (Liffey Sound volunteer). Second, for some other volunteers, the skills learned within the stations are seen as useful in seeking paid employment elsewhere or indeed, eventually securing a paid position within the station itself (the majority of staff interviewed began as volunteers). And third, allied to this, many volunteers spoke of the confidence they have gained through their work within the stations. 
A volunteer from Ros FM who comes in to produce and broadcast a music show twice a week expresses this well. "I was a person who felt myself apart from my own social group. I never really felt part of the town until I did this... I was always from here but I never really fit in... but now have an outlet to speak to everybody". Within a broader public sphere dominated by elites, this confidence building function is an important first step in opening up the sphere, bringing more marginalised voices in.

Thus, in drawing more marginalised voices and sections of the community into the stations as well as covering more localised news and events, community radio in Ireland does correspond to a widening of the public sphere as theorised by deliberative democrats and community media scholars alike. However, with a focus on the skills and competencies acquired by volunteers together with the information and entertainment function for the broader community, stations appear to function more as a service to the local population complementing some of the other state-funded social services in the area, rather than as a medium for opening debate and dialogue on diverse issues. To interrogate this further, we need to turn to an examination of the communication norms within the stations.

\section{Communication norms: the quality versus inclusion dilemma}

As we have seen, the rational, consensus-based communication norms advocated by Habermas have been the subject of much debate and critique among broader theorists. 'Difference democrats' in particular have argued that norms of 'reasoned argument' mitigate against norms of inclusion as marginalised groups often tend to employ more embodied, emotional communication acts which, highlighting their own marginalised status in society. They also emphasise the conflictual rather than consensual nature of this society. For these theorists and for a number of community media scholars, at the core of a defeudalisation of the public sphere is the capacity of community media to accommodate a diverse range of discourses and communication acts.

These normative conditions rest on an acceptance that community media occupy a very distinct space within the broader mediapolis, diversifying the public sphere rather than competing with other institutions within it. However, in a media sphere dominated by mainstream broadcasters, this perhaps overestimates the public appetite for diversity and change. In the Irish context, this is clearly manifest in what we call here the 'quality versus inclusion dilemma' for community stations. This 'quality versus inclusion' issue is generally not so polarised as this characterisation suggests but nonetheless emerged repeatedly in interviews and discussions with staff and managers within all four stations as they stressed the importance of maintaining high production values in a competitive market. While ardent community radio activists stress the 'right to communicate' for all, managers within the four stations noted the difficulties this poses when faced with a volunteer whose style may be 
perceived as 'unprofessional' by some listeners, or worse still, cause offence. As the manager of Ros FM explains “...audiences are very sophisticated. They wouldn't be very forgiving. You're only as good as your last show and so you have to be consistent with your standards." The manager in Tipperary MW is quite emphatic about it "If they're not good enough, they won't go on. It's a decision unfortunately we have to make". In a medium competing for listenership among an audience used to high standards (for what's the point in having the right to communicate if no one is out there listening?), there is clearly some tension between the diverse communication norms espoused by deliberative theorists and the pressures exerted by norms within the broader mediasphere. Previous research on community radio in Ireland has highlighted this dilemma and argues that community radio risks being perceived as 'amateurish' (Farren, 2007). In work examining this issue more broadly, Carpentier et al. note that community media come to be presented as "unprofessional, inefficient, limited in their capacity to reach large audiences and as marginal as some of the societal groups to whom they try to give voice" (2003: 65). On the other side of the debate, Van Vuuren (2006) argues that tensions over quality in community production is part of a valuable process of decision making and constructing democracy. In the Irish case, with more 'professional' norms appearing to win out over broader communication acts and with decision-making in this area restricted to station managers and core staff, the shadow cast by the broader mediasphere appears to pose fundamental challenges to the defeudalisation of this sphere with communication norms falling far short of those espoused by deliberation theorists across the spectrum. Conscious of such difficulties in broadening the public sphere, as we have seen, a number of social theorists have advocated a role for civic associations in animating this sphere. We now turn to an examination of civic associational agency in this context in Ireland.

\section{Civic culture in Ireland}

As we have seen so far, community radio in Ireland, through its ownership, management and operating structures, embodies many of the characteristics necessary for animating local, community public spheres. However, as we have also seen, situated within the broader public sphere, stations are not immune to the dominant norms within this sphere. With a particular interest in the role of broader civic associations in promoting participation within the public sphere as advocated by deliberative and social theorists, our research examined the linkages between community stations and broader civic associations within their communities, most notably local community development groups as these espouse many of the same values and ethos as community radio advocates. Interestingly we found active links and synergies between the stations and their respective community groups in promoting community participation in stations to be quite weak. Station staff and volunteers noted that stations were open to community activists to come and generate publicity for their work and events while activists themselves (who were contacted independently by the researchers) saw no difference between these stations and local commercial broadcasters. Thus, both groups view community stations primarily as a service to the local community. With a focus on information provision, local news, and publicity for local events (as well, as we have seen, on 
community training and employment), the emphasis appears to lie more in servicing local communities rather than actively animating local public spheres. Thus, as community groups "issue press releases and use the station to do interviews in relation to specific projects" (community group in Roscommon area), the appetite for peoples' own 'right to communicate' appears low, not just among the broad community, but among those key civic associations that inhabit and animate the public sphere.

Why? Clearly, at a practical level, the time and resources required to build people's confidence to become involved (most particularly if the dominant communication norms of the mainstream public sphere are required) are enormous. Notwithstanding this, we propose a second key factor which helps explain the largely 'service' culture of Irish community stations particularly and civic culture more broadly. Here Habermas' distinction between the life-world and the system proves useful. From its independence in the 1920s, Ireland has had a long legacy of voluntary-statutory service provision. Since the 1980s, with the advent of local state-civic partnerships, this has been consolidated into formal contractual arrangements where local groups are funded to develop and deliver services locally. Habermas' 'colonisation' of the life-world by the system is thus extremely well-developed in the Irish context. With a strong local service culture developing, citizens have effectively been turned into passive consumers of services, information, entertainment as critiqued by Habermas almost half a century ago. Through what could be described as Ireland's 'Third Way politics', with the whole-scale incursion of the system into the life-world, the space and the appetite for vibrant, active debate and contestation appears somewhat muted, if not closed.

This all suggests that the challenges to the defeudalisation of the public sphere are profound most particularly given the key role of the state in regulation of community broadcasters. However, it is here that a fundamental paradox to Habermasian theory emerges. While the encroachment of the state into the broader life-world raises fundamental questions around the capacity of civic associations to actively animate and defeudalise the public sphere, the state's role in regulating community stations arguably presents real opportunities in this regard.

\section{The life-world and system: A systemic paradox}

As we have seen, the state is responsible for both the regulation and, through various funding schemes, is also one of the core funders of community radio in Ireland. Under the 2009 Broadcasting Act, the scope of state regulation is extensive and covers licensing, the ownership and management structures, programming policy and the funding and financing of community stations. Closely following the AMARC model, state regulation appears to fulfil the 'other regarding' function of state intervention as advocated by Cohen and Rogers (1995) in relation to the civic sphere more broadly. Community ownership of the stations included 
in this study is reflected in both the membership structures (cooperatives) and in the high level of voluntary participation in the respective boards, with volunteers in three of the stations (Liffey Sound, Life FM and Tipperary MW) reporting regular contact with board members who also volunteer as broadcasters in the stations. The fourth station, Ros FM, is a little different in this respect. Owned and managed by the local partnership institution comprising a range of local state-funded social services - volunteers report less contact with board members. State regulation stipulates that stations can include a maximum of 6 minutes advertising per hour of broadcasting. This further aids in preventing commercial distortions in programming although it also leaves stations heavily dependent on state funding for their

ongoing costs. Situated within communities dominated, as we have seen, by the mainstream public sphere where, with the colonisation of the life-world by the system, citizens have been reduced to consumers and dominant communication norms prevail, we propose that, paradoxically, it is state regulation (together with a handful of radical activists working closely with the state) which maintains the distinctiveness of community radio within Ireland's broader mediasphere.

In this section we have examined the opportunities provided by community stations in defeudalising the public sphere, together with the challenges posed in this regard. Among the opportunities identified in opening up this sphere is the diverse participation in volunteering, ownership and management of community stations. The volunteers we spoke and spent time with attest to the diversity of voices on the airwaves, and most for the first time. It is clear that the respective stations are successful in bringing issues of interest to their local communities, in the process reducing individuals' isolation and bringing them into a community sphere that has relevance to their lives. A key factor underpinning these opportunities is the action of the state which, through its licensing and regulation, promotes broad-based community ownership and 'other regardedness', reducing distortions and monopolisation of the local sphere. However, fundamental challenges remain as the dominant norms of both the colonised mainstream mediapolis and the colonised broader civic sector exert their influence. Communication norms fall short of deliberative and Habermasian ideals as community stations strive to compete with their mainstream counterparts, and the dynamic, catalytic function of stations catalysts for a renewed, defeudalised public sphere fall somewhat by the wayside under the shadow of the service culture which underpins the colonisation of the life-world under Ireland's distinctive brand of Third Way governance. In a context where the colonisation of the life-world by both state and market is so extensive, the fundamental paradox is that the life-world, having perhaps lost its capacity for self-renewal, is now dependent on the state for this renewal.

\section{Conclusion: Some implications for the public sphere}

The depth and scale of Ireland's economic crisis is now well-known. Less well-known, though occasionally raised by international commentators, is the paucity of debate and action 
within the domestic public sphere on this issue. Driven by the mainstream media, public debate remains saturated with the language international finance. Experts now on the vagaries of international bond markets and well-versed in the language of austerity and structural adjustment, the Irish public has had little opportunity to articulate its frustration, anger and opposition to the actions of key political elites. With the space for meaningful political debate closed, the feudalisation of the mainstream public sphere by the system appears complete.

At this time of profound crisis within Irish society, community radio provides a real opportunity to defeudalise local, community level spheres. Yet, the stunning irony is that the life-world, saturated by the system, appears to have has lost capacity for self-renewal. Clearly, Habermas was right. Yet, paradoxically, Habermas was perhaps also wrong. Real opportunities exist in the progressive state policy and regulation of community radio to reclaim communities sphere(s), to broaden the debate from the interests, concerns and analyses of the market to those of our own communities. The challenge to community radio activists is to seize this opportunity, to reinvigorate and recharge the public sphere, in the process, re-animating and defeudalising public life.

\section{References}

AMARC. 1994. AMARC Europe Charter. 〈http://www.amarc.org>

BAI (Broadcasting Authority of Ireland). 2009. Broadcasting Bill. Dublin: Stationary Office.

Baker, Sarah. 2007. Young People and Community Radio in the Northern Region of Adelaide, South Australia. Popular Music and Society 30, 5, 575-590.

Barlow, David and Steve Johnson. 2008. Finding a Voice Community Radio: Role, Sustainability and Practice. The Radio Journal 6, 2\&3, 75-85.

Barlow, William. 1988. Community Radio in the U.S.: The struggle for a democratic medium. Media, Culture and Society. 10, 1, 81-105.

BCI (Broadcasting Commission of Ireland) (n.d.) BCI Policy on Community Radio Broadcasting, Dublin: Stationary Office.

Benhabib, Seyla. 1996. Toward a Deliberative Model of Democratic Legitimacy. In S. Benhabib (ed.), Democracy and Difference, 67-94. New Jersey: Princeton University Press.

Brady, John S. 2004. Assessing the Agonistic Critiques of Jürgen Habermas' Theory of the Public Sphere. Philosophy and Social Criticism 30, 3, 331-354.

Carpentier, Nico., R. Lie and J. Servaes. 2003. Community Media Muting the Democratic Discourse Continuum. Journal of Media and Cultural Studies. 17, 1, 51-68.

Cohen, Jean L. and Andrew Arato. 1992. Civil Society and Political Theory. Cambridge MA: MIT Press. 
Cohen, Joshua and Joel Rogers. 1995. Associations and Democracy. London: Verso.

Dahlberg, Lincoln. 2005. The Habermasian Public Sphere: Taking Difference Seriously? Theory and Society 34, 2, 111-136.

Dahlgren, Peter. 2002. In Search of the Talkative Public: Media, Deliberative Democracy and Civic Culture. Javnost - The Public 9, 3, 5-26.

Dryzek, John. 1990. Discursive Democracy: Politics, Policy and Political Science. Cambridge: Cambridge University Press.

Dryzek, John. 2000. Deliberative Democracy and Beyond: Liberals, Critics, Contestations, Oxford: Oxford University Press.

Forde. S., K. Foxwell and M. Meadows. 2002. Creating a Community Public Sphere: Community Radio as Cultural Resource. Media International Australia 103, 56-67.

Fraser, Nancy. 1992. Rethinking the Public Sphere: A Contribution to the Critique of Actually Existing Democracy. In C. Calhoun (ed.), Habermas and the Public Sphere, 109-142. Cambridge MA: MIT Press.

Gaynor, Niamh and Anne O'Brien. 2010. Drivers of Change?: Community Radio in Ireland. <http://www.bai.ie/publications_researchpub.html>

Habermas, Jürgen. 1987. Theory of Communicative Action: Volume 2. Boston: Beacon Press.

Habermas, Jürgen. 1989. The Structural Transformation of the Public Sphere: An Enquiry into a Category of Bourgeois Society. Cambridge, Mass: MIT Press.

Habermas, Jürgen. 1996. Between Facts and Norms. Cambridge, Mass: MIT Press.

Holub, R. C. 1991. Jürgen Habermas: Critic in the public sphere. London: Routledge.

Jankowski, Nicholas W. 2003. Community Media Research: A Quest for Theoretically Grounded Models. Javnost - The Public 10, 1, 5-15.

Jankowski, Nicholas W. and O. Prehn. 2003. Community Media in the Information Age: Perspectives and Prospects. New Jersey: Hampton Press, 47-61.

Karppinen, Kari, Hallvard Moe and Jakob Svensson. 2008. Habermas, Mouffe and Political Communication: A Case for Theoretical Eclecticism. Javnost - The Public 15, 3, 522.

Keogh, Sara Beth. 2010. The importance of place in community radio broadcasting: a case study of WDVX, Knoxville, Tennessee. Journal of Cultural Geography 27, 1, 77-98.

Lewis, P. 2002. Radio Theory and Community Radio. In N. Janowski \& O. Prehn (eds.) Community Media in the Information Age, Perspectives and Prospects, 359-375. New Jersey: Hampton Press.

Martin, Kirsty and Michael Wilmore. 2010. Local voices on community radio: a study of 'Our Lumbini' in Nepal. Development in Practice 20, 7, 866-878.

Meadows, Michael, Susan Forde, Jaqui Ewart and Kerrie Foxwell. 2005. Creating an Australian Community Public Sphere: The Role of Community Radio. The Radio Journal 3, 3, 171-187.

Mouffe, Chantal. 1996. Democracy, Power and the Political. In S. Benhabib (ed.), Democracy and Difference, insert page numbers. New Jersey: Princeton University Press.

Mouffe, Chantal. 2005. On the Political. London and New York: Routledge.

Reed, Maryanne and Ralph E. Hanson. 2006. Back to the Future: Allegheny Mountain Radio and Localism in West Virginia Community Radio. Journal of Radio Studies 13, 2, 214-231.

Saeed, Saima. 2009. Negotiating Power: Community Media, Democracy and the Public Sphere. Development in Practice 19, 4/5, 466-478.

Siemering, William. 2000. Radio, Democracy and Development: Evolving Models of Community Radio. Journal of Radio Studies 7, 2, 373-378. 
Silverstone, R. 2007. Media and Morality: on the rise of the mediapolis. Cambridge: Polity Press.

Splichal, Slavko. 2002. The Principle of Publicity, public use of reason and social control. Media, Culture and Society, 24, no.?? 5- 26.

Stiegler, Zack. 2009. Conceptualising the Small-scale Public Sphere. Javnost-The Public. $16,2,41-60$.

Sussman, Gerald and J. R. Estes. 2005. KBOO Community Radio: Organizing Portland's Disorderly Possibilities. Journal of Radio Studies 12, 2, 223-239.

Van Vuuren, Kitty. 2006. Community Broadcasting and the enclosure of the Public Sphere. Media, Culture and Society. 28, 3, 379-392.

Young, Iris Marion. 2000. Inclusion and Democracy. Oxford: Oxford University Press.

Young, Iris Marion 2003. Activist Challenges to Deliberative Democracy. In James Fishkin and Peter Laslett (eds.), Debating Deliberative Democracy, 102-120. Malden MA: Wiley-Blackwell. 